\title{
The EFL Pre-Services Teachers' Pedagogical Competence Based on the Instructional Approach
}

\author{
Sumani, Samsul Arifin \\ Universitas PGRI Madiun, UNIPMA \\ Madiun, Indonesia \\ samsul0442@gmail.com
}

\begin{abstract}
A competence teacher has an important role in students' success. Thus improving the pedagogical competence of teachers seems to be very important too. This attempt, at first hand, requires recognizing the pedagogical competence of teachers. To meet such requirement, the class of microteaching is designed to improve pre-service teachers' pedagogical competence. Therefore, the purpose of this study was to describe the EFL pre-service teachers' pedagogical competence based on the instructional approach. To cope with such problem, a case study is implemented to five microteaching classes consisting of 53 pre-service teachers. The research data were obtained through questionnaires, observation, and interview. The data validity was strengthened by conducting intensive long-term participant involvement in producing a complete and in-depth understanding of field situations, triangulation to collect converging evidence from different sources by applying either the technique triangulation and data source triangulation, and testing rival or competing explanations. Data analysis was performed by applying Interactive Analysis Model namely data condensation, data display, and conclusion drawing/verification. The result shows that the pre-service teachers are good at introductory and closure skills, explanation, group and individual teaching, and teaching variation, classroom management, and assessing. Hence, they are lacks on questioning and reinforcement. Therefore, it is suggested to microteaching lecturers to use this approach in the microteaching class, on the other hand, they are also suggested to focus more on those lacking aspects during the microteaching process.
\end{abstract}

Keywords-Microteaching; Pedagogical Competence; Preservice Teacher; Instructional Approach

\section{INTRODUCTION}

Microteaching is a way of learning used in teacher education and various learning situations, which aims to improve the behavior and ability of teachers toward learning (Baytekin, 2004). In addition, microteaching is one form of practice model of education containing many complex acts of teaching, both including technical delivery of material, the use of the method, the use of media, guiding learning, motivating, managing a classroom, assessing, etc (Rosyidah, 2011). Thus, microteaching is a learning process implemented as a process of preparing Indonesian Pre-services teachers pedagogical competence before deployed on the activities of Inservice Training Program Field Experience Practices $(P P L)$ which are based on promoting students' performance such a way to accomplish the components of the learning process so that the EFL pre-services teachers can master each component individually in simplified or minimized situations. Furthermore, the objectives of micro teaching class are to improve teacher's pedagogical competence, which means mastering four basic skills of teaching. Such skills include introductory and closure skills, classroom management, reinforcement, group and individual teaching, questioning, explaining, teaching variation, and assessing (Saud, 2009).

Microteaching is conducted based on the rationality expected to form a professional teacher as contained in the Act of Teachers and Lecturers number 14 of 2005 which states that teachers including English must have competence in the field. According to Spencer and Spencer (1993) competency is an underlying characteristic of a person related to the effectiveness of individual performance on the job or the basic characteristics of individuals who have a causal relationship or a cause and effect with the criteria referenced, effective or excellent or superior performance in the workplace or in certain situations. In an educational context, competence means a set of knowledge, skills, and behaviors that must be owned, internalized, and mastered by teachers in carrying out their professional duties which include pedagogical, social, personal, and professional. Pedagogical competence is "the ability of an individual to use a coordinated, synergistic combination of tangible resources (e.g. instruction materials such as books, articles, and cases and technology such as software and hardware) and intangible resources (e.g. knowledge, skills, experience) to achieve efficiency and/ or effectiveness in pedagogy" (Madhavaram and Laverie, 2010). It covers the ability to understand students, designing and implementing the learning and evaluating learning outcomes as well. Social competence includes procedures for teacher community and cooperates effectively with all elements of education. Professional competence is the ability to analyze, develop, and evaluate and the effectiveness of the learning process and learning innovation. Meanwhile, personal competence includes the ability to be mature, wise, dignified, and noble, be a good example, be polite, and have a work ethic and professionalism of high responsibility (Hakim, 2015)

However, facts show that Indonesian pre-services teachers are still having some problems. The results of the interview and also observing the learning process of micro teaching at IKIP PGRI Madiun, it can be said Pre-Services Teachers are having experienced problems to achieve the objectives of the class. Based on the interview data gained 
from stakeholders, namely the schools where students carry out teaching practice $(P P L)$, it shows that students are less skilled in managing learning period. They are still weak in terms of managing for each sub-activity which is included in the lesson plans they have made. This resulted in ineffective learning activities and learning objectives as stated on lesson plan are not achieved. In addition, there are still many students who are weak in developing methods and learning models. Most of the students are still often using conventional methods such as one-way lecturing. Furthermore, there are still many students who have not been able to use the learning media well and also create innovative ones. Moreover, they are also still having problems with mastery of classroom language so that the instructions given are difficult to understand and it affects on students' mastery of learning materials.

Based on the observation of micro teaching class, interviewing the students, as well sharing with the lecturers, it was found that the problem arouses since the students are still less confident when they carry out their teaching practice so that it affects on the lack of mastery of the class who then also impacting the classroom situation into less dynamic and less responsive. Secondly, the supervising process from lecturers is still not optimal. This happens because of the limited time of guiding while the numbers of students who must be guided are quite large. As a result, students are still having many difficulties in a variety of ways. For example, they are still having difficulties in designing lesson plan $(R P P)$ and implementing the model of specific learning.

To solve the problems, an instructional approach is proposed. An instructional approach is an approach to education that is used to convey the knowledge into the learning process (Petrina, 2000). It is characterized by certain regularities in the ways in which teachers and students interact with each other and with instructional materials that can be described, evaluated, and replicated (Cohen and Ball, 1999). To implement instructional approach actively, Glickman (1991) states that effective teachers do not use the same set of practices for every lesson. Instead, what effective teachers do is constantly reflect about their work, observe whether students are learning or not, and, then adjust their practice accordingly. Therefore, Corcoran dan Silander (2009) suggest that a highly effective instructional approach or "best practice" is one that results in measurable improvements in performance on examinations or standardized tests. In addition, effective teaching is not a set of generic practices, but instead is a set of context-driven decisions about teaching.

From the concept of Instruction Approach frameworks, the implementation of the instructional approach in micro teaching classes is divided into 4 phases namely preparation stage, pre-activities stage, whilst-activities stage, and post-activities stage. In the preparation stage, students are required to identify the skills and appropriate activities, and analyze student competencies, linguistic skills, learning objectives, learning indicators, and understand the characteristics of students to design appropriate strategies; select models of learning (learning approaches, teaching methods, and learning technique); relate the approach with learning objectives; design learning activities between teachers and students, students and students, and students with materials in line with the objectives and learning model; and develop detail script or scenario which covers eight basic skills of teaching. In pre-activities stage, the student should consult the result of analysis, approach, detail activities and scenario to the lecturers; revising the document, and do the final consultation for activities. In whilst stage, the student should apply the 8 basic skills of teaching and make it appropriate for the scenario that has been consulted and select appropriate solutions based on the theory of 8 teaching basic skills to problems that arise accidentally during the learning process. In post activities, the lecturers give an evaluation of the teaching process and provide feedback on eight basic skills of teaching.

From those explanations, it can be clearly shown in the following chart

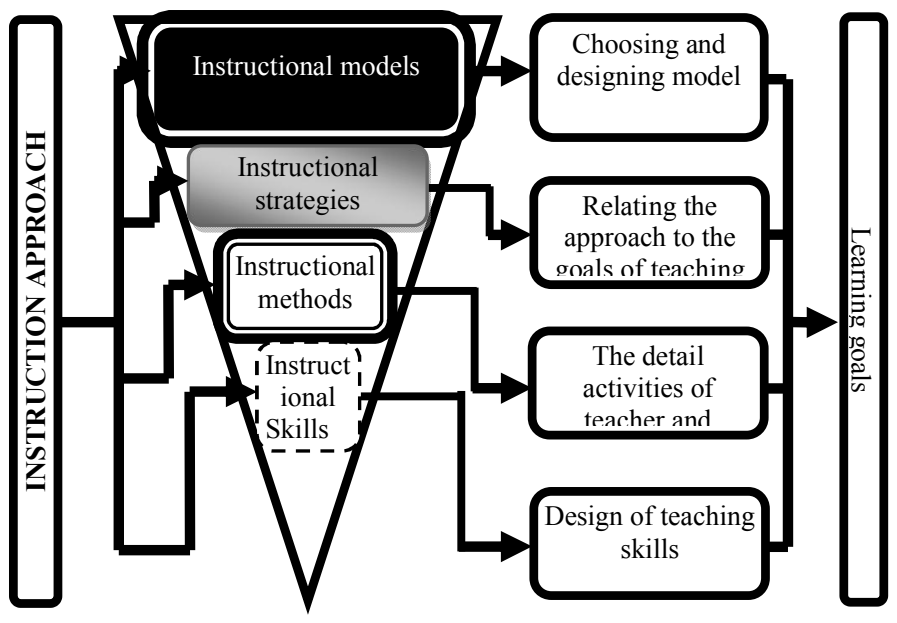

Figure 1. Framework Instruction Approach

\section{METHOD}

A case study is implemented to five classes of micro teaching consisting of 53 pre-service teachers. The research data were obtained through questionnaires, observation, and interview. The data validity was strengthened by conducting intensive long-term participant involvement in producing a complete and in-depth understanding of field situations, triangulation to collect converging evidence from different sources by applying either the technique triangulation and data source triangulation, and testing rival or competing explanations. Data analysis was performed by applying Interactive Analysis Model namely data condensation, data display, and conclusion drawing/verification.

\section{FINDING AND DISCUSSION}

The interview has been done to the teacher and students. The results showed that by using this model, 
instructional practices of micro teaching can be carried out smoothly. The Lesson Plan is made through the consultation process so the microteaching is well organizing. On the other hand, $9.1 \%$ of respondents stated that the learning process by implementing instructional approach is not good enough because the process of drafting and consultation requires great effort and time. (2) Respondents' interest in participating in the class of microteaching is good. A total of $81.8 \%$ of respondents used instructional approach models because this model strengthens their abilities in formulating the detail activities, provides innovation in classroom activities and determine the appropriate indicators of English skills. On the other hand, $18.2 \%$ of respondents stated that less interested in following the learning process with this model. The model is quite difficult to adjust schedules due to lesson plans consultation with the teacher. (3) Teaching activities in microteaching-based instruction detail. A total of $90.9 \%$ of respondents stated that there is activity in the model to support their innovative activities in the classroom. In addition, each step also improves the students' pedagogical ability. (4) Respondents noted that this model makes teaching process is more interesting, they are able to increase the knowledge of students in designing innovative and active learning, they can arrange suitable indicators, they can make good assessment and evaluation in line with certain skill, and they get an easier ways to develop a learning scenario.

The observation on the implementation of instructional approach on microteaching class shows that the strength is improving students' introductory and closure skills including attracting students attention on brainstorming activity, positioning, choosing the appropriate activities to the topic, summarizing the learning, and giving homework. In addition, it also improves students' classroom management including handling group work activities, giving clear instruction, handling possible actions bothering the class, and giving attention to the students. Explaining skills of the preservices teachers are also improved in terms of using an effective classroom languages, providing lots of relevant examples, and giving specific feedbacks. Those happen since the pre-services teachers are doing the stages of an instructional method which lead them into peer-discussion toward lesson plan and also expert-consultation/ lecturer to design an interactive and meaningful learning activities. Inkelas, Bach, and Roska (2014) state that student learning is better achieved through a dynamic process that engages student motivation and active learning. It is also supported by Wolfe (2015) who states,

Students engage in learning by constructing group solutions, texts, experiments, or works of art. Effective group work is well planned and strategic. Students are grouped intentionally, with each held accountable for contributing to the group work. Activities are designed so that students with diverse skill levels are supported, as well as challenged by their peers. They are planned around meaningful tasks in the subject area that is conceptually rich, engaging, with multiple entry points.

The pre-services teachers' group and individual teaching skill are also improving in the aspects of providing fun learning activities, encouraging students' participation to argue and finish their task well, giving advice and honor to the students' result, and activities planning.

Instructional skills describe what
personalized, learner-centered educators
need to do to bring distinctly learner-
centered pedagogical techniques into the
classroom. These include creating engaging
and relevant curriculum, managing
classroom dynamics, and using
instructional approaches and methods that
build toward and assess mastery. (Wolfe,
2015)

The improvement also occurs to the aspects of teaching variation which includes having a variation on intonation, effective sentences, teaching media, teaching technique, and strategy. Last, the instructional approach also improves students skill on doing assessment including aspects of paying attention to students who experience difficulties, conduct assessments to students about what has been received, finding the source of the trouble, and conduct activities to address the difficulties.

Hence, they are lacks on questioning and reinforcement. The lack of questioning skill includes providing information to be a reference question, convergence towards an answer which is requested, and the provision of guidance. While the lack of reinforcement includes reinforcement by approaching the students and fun activities.

\section{CONCLUSION AND SUGGESTION}

The application of Instructional Approach on Microteaching class eases the process of preparing lesson plans, implementing and evaluating learning, and also strengthen the pre-services teachers' pedagogical competence in the aspects of introductory and closure skills, explaining, group and individual teaching, and teaching variation, classroom management, and assessing. Hence, they cannot accommodate the aspects of questioning and reinforcement well. In relation to this, it is suggested to microteaching lecturers to use this approach in the microteaching class and they are also suggested to focus more on those lacking aspects during the micro teaching process..

\section{References}

Allen, D. W. \& Wang, W. P. (1996), Micro-teaching. Beijing: Hsin Hua Publishers.

Baytekin, Ç. (2004). Learning Teaching Techniques and Material Development. Ankara: Anı Yayıncılık. 
Cohen, K. D. \& Ball, L. D. (1999). Instruction, Capacity, and Improvement. Consortium for Policy Research in Education. Pensylania: Graduate School of education press.

Corcoran, T. \& Silander, M. (2009). Instruction in High Schools: The Evidence and Challenge. The Future of Children, Vol. 19 No. 1 Hal. 157-183.

Dick, W. \& Carey, L. (1990). The Systematic Design of Instruction: Third Edition. New York: Harper Collins Publishers.

Dongsong, Z. (2005). Interactive Multi-media-Based E-Learning: A Study of Effectiveness. The American Journal of Distance Education. New York: Lawrence Erlbaum Association, Inc.

Glickman, C. (1991). Pretending Not to Know What We Know. Educational Leadership, 48, 4-10

Hakim, A. (2015). Contribution of Competence Teacher (Pedagogical, Personality, Professional Competence, and Social) On the Performance of Learning. The International Journal of Engineering And Science (IJES). Vol. 4 No. 2, 01-12

Inkelas, Bach, Roska. (2014). Introducing and Assessing Learner-Centered Principles To and Among the Next Generation of College Professors. Conference on Higher Education Pedagogy. February 5-7, 2014. The Inn at Virginia Tech and Skelton Conference Center Virginia Tech, Blacksburg, Virginia

Madhavaram, S., Laverie, D.A. (2010). Developing Pedagogical Competence: Issues and Implications for Marketing Education. Journal of Marketing Education, vol. XX, no X, 2-10

Miles, Huberman, and Saldana. (2014). Qualitative Data Analysis: A Methods Sourcebook. USA: SAGE Publications, Inc.

Palmer, A. P. (2003). 50 Pemikir Pendidikan: Dari Piaget Sampai Masa Sekarang. Yogyakarta: Jendela.

Petrina, S. (2004). The Politics of Curriculum and Instructional Theory: Critical Problems, Projects, Units, and Module. Interchange, vol. 35 no. 1 page 81-126.

Rosyidah, A. (2011). Urgensi Micro Teaching sebagai Upaya Meningkatkan Kompetensi Guru Peserta Diklat Guru Mata Pelajaran Bahasa. Surabaya: Balai Diklat Keagamaan.

Saud, U. S. (2009). Pengembangan Profesi Guru. Bandung: CV. Alfabeta.

Spencer, LM, and Spencer, SM, 1993. Competence at Work: Models for Superior Performance. New York: John Wiley \& Sons.

Wolfe, E. R. (2015). Educator Competencies for Personalized, TeacherCentered Learning. Boston: Job for the Future and the council.

Yin, Robert K. (2011). Qualitative Research from Start to Finish. New York: The Guilford Press. 